\title{
Pengaruh kualitas pelayanan, harga, dan lokasi terhadap kepuasan pelanggan PT.Dwi Karya Sartika
}

\author{
Fenny Krisna Marpaung*; Irma N.Hutagalung; Maria Mariana \\ Tinambunan; Nico Jeremi Siahaan; Lamhoras H.Siregar
}

\author{
Prodi Manajemen, Fakultas Ekonomi Universitas Prima Indonesia \\ *E-mail korespondensi: irmahutagalung1@gmail.com
}

\begin{abstract}
The purpose of the implementation of this research is to prove and determine the magnitude of the influence of the independent variable of service quality, the independent variable of price, and the independent variable of location on the dependent variable of customer satisfaction at PT.Dwi Karya Sartika Medan. The sampling technique used was random sampling, thus the sample used was to carry out regression testing on 84 research respondents and 30 study respondents to carry out the reliability and validity test. Hypothesis testing is to use multiple linear regression analysis. The results of the research implementation of the independent variable of service quality, the independent variable of price, and the independent variable of location contributed partially to the dependent variable of customer satisfaction PT.Dwi Karya Sartika. The result of the test of the coefficient of determination is 0.758 , which means that the resulting or predicted influence of the free variable of service quality $\left(X_{1}\right)$, price free variable $\left(X_{2}\right)$, and location independent variable $\left(X_{3}\right)$ on the dependent variable of customer satisfaction $(Y)$ is $75.8 \%$, while the remaining $24.2 \%$ is predicted or influenced by independent variables which are not included in the implementation of this research.
\end{abstract}

Keywords: Service quality, Price, Location, Customer satisfaction.

\begin{abstract}
Abstrak
Tujuan dari pelaksanaan penelitian ini agar membuktikan dan mengetahui besaran pengaruh dari variabel independen dari kualitas pelayanan, variabel independen harga, dan variabel independen lokasi pada variabel dependen kepuasan pelanggan PT.Dwi Karya Sartika Medan. Teknik dalam pengambilan sampel mempergunakan random sampling, dengan demikian sampel yang dipergunakan ialah untuk melaksanakan pengujian regresi pada 84 responden penelitian dan 30 responden penelitian untuk melaksanakan uji reliabilitas dan juga validitas. Pengujian hipotesis ialah dengan mempergunakan analisis regresi linier berganda. Hasil dari pelaksanaan penelitian variabel bebas dari kualitas pelayanan, variabel bebas harga, dan variabel bebas lokasi memberikan sumbangan pengaruh pada variabel terikat dari kepuasan pelanggan PT.Dwi Karya Sartika secara parsial. Hasil dari pengujian koefisien determinasi ialah senilai 0,758, dengan ini mengandung makna bahwa pengaruh yang dihasilkan atau diprediksikan dari variabel bebas kualitas pelayanan $\left(\mathrm{X}_{1}\right)$, variabel bebas harga $\left(\mathrm{X}_{2}\right)$, dan variabel bebas lokasi $\left(\mathrm{X}_{3}\right)$ pada variabel terikat dari kepuasan pelanggan $(\mathrm{Y})$ adalah senilai $75,8 \%$, sedangkan untuk sisa senilai $24,2 \%$ diprediksikan atau dipengaruhi oleh variabel-variabel independen yang tidak dimasukkan dalam pelaksanaan penelitian ini.
\end{abstract}

Kata kunci : Kualitas pelayanan, Harga, Lokasi, Kepuasan pelanggan.

\section{PENDAHULUAN}

Sepeda motor ialah sarana untuk transportasi yang umum dipergunakan oleh mayoritas penduduk di Negara Indonesia. Jumlah dari pengguna kendaraan bermotor 
mengalami peningkatan yang banyak yang memerlukan sarana guna memperbaiki ataupun merawat kendaraan supaya masih sesuai untuk dipergunakan, tetap baik dan juga di kemudian hari memiliki daya jual yang tetap tinggi. Potensi peluang semacam ini menyebabkan persaingan yang tinggi yang terjadi antara bengkel, khususnya untuk dealer perusahaan resmi yang melaksanakan kooperatif terhadap merek sepeda motor tertentu yang melaksanakan persaingan dalam memperoleh pelanggan pengguna jasa dealer.

PT Dwi Karya Sartika merupakan bengkel resmi sepeda motor merek Honda. Perusahaan ini terletak di JL.Gaperta no.234 B Kec.Medan Helvetia.Selain melakukan service sepeda motor, PT. Dwi Karya Sartika juga menjual suku cadang asli Honda dengan berbagai merek. PT Dwi Karya Sartika merupakan salah satu perusahaan jasa yang lebih mengutamakan mutu pelayanan yang bagus guna membuat puas keperluan dari pengguna jasa supaya dapat mencapai target dan tujuan perusahaan.

Terdapat beberapa faktor-faktor yang mempengaruhi kepuasan yang didapatkan pelanggan, diantaranya ialah lokasi, kualitas pelayanan dan juga harga itu sendiri. Hal ini sejalan terhadap hasil dari pelaksanaan penelitian yang dilaksanakan Firdiyansyah (2017). Berdasarkan observasi yang peneliti lakukan terdapat beberapa fenomena yaitu kualitas pelayanan yang masih kurang maksimal di mana masih terdapat kritik dan saran dari konsumen. Pelayanan konsumen dinilai masih kurang sehingga konsumen yang ingin servis kendaraan kadang memerlukan waktu yang panjang dan untuk hasil yang didapatkan kadang tidak sesuai dengan keinginan dari pengguna layanan jasa. Untuk harga yang dijual, beberapa produknya relatif lebih tinggi dibandingkan bengkel-bengkel lain dikarenakan PT Dwi Karya Sartika (AHASS 17193) merupakan perusahaan resmi honda, sehingga produk yang dijual dijamin keasliannya oleh karena itu tidak sedikit konsumen yang tetap membeli produk langsung di AHASS 17193.

Merujuk pada pemaparan latar belakang fenomena dan masalah yang diuraikan tersebut di atas, dengan demikian memiliki ketertarikan untuk melaksanakan penelitian berkenaan dengan "Pengaruh kualitas pelayanan, harga, dan lokasi terhadap kepuasan pelanggan PT.Dwi Karya Sartika"

\section{LANDASAN TEORI}

\section{Teori pengaruh kualitas pelayanan terhadap kepuasan pelanggan}

Merujuk pada uraian penjelasan yang dikemukakan oleh Yuniarti (2015:233) menjelaskan bahwa konsumen akan merasakan kepuasan bilamana pelayanan atau servis yang diberikan oleh penyedia jasa dan produk dapat membuat senang perasaan dari para pengguna jasa.

Merujuk pada uraian penjelasan yang dikemukakan oleh Sudaryono (2016: 93) menjelaskan bahwa strategi menghasilkan kepuasan pelanggan dan kualitas pelayanan ialah dengan memperhatikan dengan seksama keluhan yang dialami oleh pengguna jasa, berupaya menghasilkan layanan yang paling baik, menetapkan standar kinerja dan juga ukuran, memberikan hak dan juga perlindungan pada hak-hak dari para pegawai, melatih para pegawai supaya menghasilkan pelayanan yang baik.

Merujuk pada uraian penjelasan yang dikemukakan oleh Tjiptono (2012: 157) menjelaskan bahwa kualitas pelayanan ialah berkenaan dengan ukuran baik atau buruk tingkatan pelayanan yang dihasillkan tersebut sudah tepat dengan harapan dari para pengguna jasa.

\section{Teori pengaruh harga terhadap kepuasan pelanggan}

Merujuk pada uraian penjelasan yang dikemukakan oleh Abdurrahman (2015:109) menjelaskan bahwa harga memiliki sumbangsih pengaruh terhadap keuntungan yang 
didapatkan oleh suatu perusahaan secara langsung. Harga juga memiliki peranan pokok dalam menghasilkan nilai dari pengguna jasa serta membentuk keterhubungan terhadap pengguna jasa.

Merujuk pada uraian penjelasan yang dikemukakan oleh Hasan (2014:103) menjelaskan bahwa pelanggan memiliki kesediaan untuk melaksanakan pembayaran sejumlah harga yang lebih tinggi guna memperoleh kualitas dan pelayanan yang lebih bagus. Strategi yang lebih memfokuskan terhadap kepuasan yang didapatkan pengguna jasa ialah

pilihan yang paling baik dalam upaya untuk menjaga pengguna jasa terhadap produsen lain yang menyediakan biaya yang lebih kecil.

Merujuk pada uraian penjelasan yang dikemukakan oleh Sunyoto (2014:130) menjelaskan bahwa harga yang ditentukan tersebut terlalu tinggi atau justru terlalu murah pada barang dengan mutu tertentu, bilamana penerapan harga dari suatu produk tersebut terlalu tinggi namun tidak sejalan dengan mutu dari produk tersebut, dengan demikian pelanggan akan memilih opsi lain dalam membeli barang di kemudian hari.

\section{Teori pengaruh lokasi terhadap kepuasan pelanggan}

Merujuk pada uraian penjelasan yang dikemukakan oleh Fahmi (2014: 54) menjelaskan bahwa lokasi produksi memberikan pengaruh pada letak dari sebuah aktivitas produksi di tempat yang tepat terhadap cangkupan bisnis itu sendiri.

Merujuk pada uraian penjelasan yang dikemukakan oleh Tjiptono (2015:345) menjelaskan bahwa lokasi ini merujuk pada beberapa aktivitas dari pemasaran yang berupaya untuk mempermudah dan memperlancar pengukuran dan pencapaian jasa dan barang yang berasal dari produsen pada pelanggan.

Merujuk pada uraian penjelasan yang dikemukakan oleh Sunyonto (2015:176) mengungkapkan bahwa lokasi strategis memberikan sumbangan pengaruh terhadap banyaknya calon konsumen, hal ini mengandung makna bahwa lokasi yang strategis akan mudah ditemui oleh calon pelanggan dan lokasi yang ramai dengan calon pelanggan untuk membeli atau mempergunakan jasa dan juga barang.Kerangka konseptual Merujuk pada penelitian yang sudah dilaksanakan dan juga teori yang dikemukakan tersebut di atas, dengan demikian di dalam pelaksanaan penelitian ini dapat dihasilkan kerangka konseptual sebagaimana gambar di bawah ini:

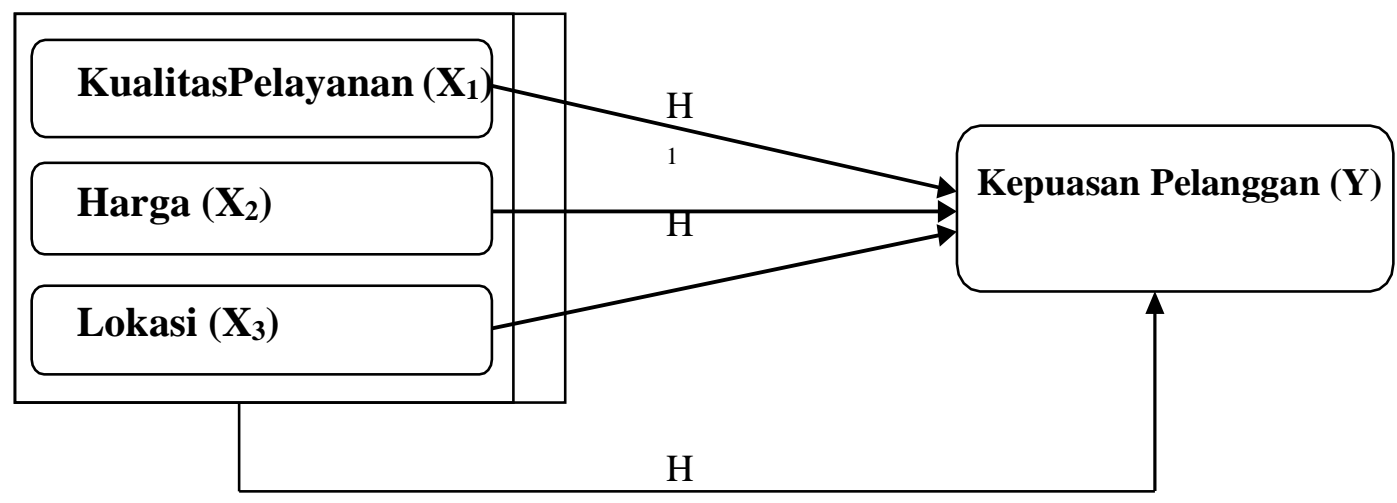

Gambar I. Kerangka konseptual

Merujuk pada kerangka konseptual yang disajikan tersebut di atas, dengan demikian bisa dihasilkan rumusan berkenaan dengan hipotesis penelitian sebagaimana di bawah ini: 
$\mathrm{H}_{1}$ : variabel bebas dari Kualitas pelayanan memberikan sumbangan pengaruh signifikan dan positif pada kepuasan yang didapatkan oleh pelanggan dari perusahaan PT. Dwi Karya Sartika.

$\mathrm{H}_{2}$ : variabel bebas dari harga memberikan sumbangan pengaruh signifikan dan positif pada kepuasan yang didapatkan oleh pelanggan dari perusahaan PT. Dwi Karya Sartika.

$\mathrm{H}_{3}$ : variabel bebas dari lokasi memberikan sumbangan pengaruh signifikan dan positif pada kepuasan yang didapatkan oleh pelanggan dari perusahaan PT. Dwi Karya Sartika.

$\mathrm{H}_{4}$ : variabel bebas dari lokasi, kualitas pelayanan dan juga harga memberikan sumbangan pengaruh signifikan dan positif pada kepuasan yang didapatkan oleh pelanggan dari perusahaan PT. Dwi Karya Sartika.

\section{METODE}

\section{Lokasi penelitian}

Lokasi dari pelaksanaan penelitian dalam penelitian ini beralamat pada AHASS 17193 PT. Dwi Karya Sartika jalan Gaperta No. 234 B Kec. Medan Helvetia. Waktu penelitian ini dari tanggal 12 april 2019 sampai dengan selesai.

\section{Jenis penelitian}

Jenis dari pelaksanaan penelitian ialah penelitian kuantitatif yang mempergunakan metode deskriptif, sedangkan sifat dari penelitian yang dipergunakan ialah penelitian eksplanatif.

\section{Populasi dan sampel}

Di dalam pelaksanaan penelitian ini ialah pelanggan atau pengguna jasa PT. Dwi Karya Sartika yang berjumlah 533 orang. Di dalam pelaksanaan penelitian ini, teknik yang dipergunakan dalam pelaksanaan pengambilan sampel ialah mempergunakan random sampling, yakni penambilan sampel dilakukan secara random atau acak. Jumlah dari sampel atau responden penelitian ini dilaksanakan pengkalkulasian dengan mempergunakan formulasi dari slovin, yang mana tingkatan kesalahannya ialah $10 \%$. Maka ukuran sampel adalah:

Di dalam pelaksanaan penelitian ini

$$
n=\frac{N}{\mathrm{~N} \cdot \mathrm{d}^{2}+1}
$$

\section{Keterangan :}

$\mathrm{n} \quad=$ Besaran sampel

$\mathrm{N} \quad=$ Besaran populasi

$\mathrm{d}=$ = Presisi yang ditetapkan $10 \%$

Dengan demikian, sampel yang didapatkan ialah sebagaimana di bawah ini:

$$
\begin{aligned}
n & =\frac{N}{\mathrm{~N}^{2}+1} \\
n & =\frac{533}{533(0,1)^{2}+1} \\
& =84,2
\end{aligned}
$$

Berdasarkan perhitungan jumlah sampel dalam penelitian ini di yaitu 84,2. 
Sehingga jumlah responden yang dijadikan sampel sebanyak 84 orang.

\section{Teknik pengumpulan data}

Di dalam pelaksanaan pengumpulan data, metode yang dipergunakan ialah dengan melaksanakan studi kepustakaan (study literature), pewawancaraan (interview) dan juga menyebarkan angket kuisioner.

\section{Uji validitas dan reliabilitas}

\section{Uji validitas}

Merujuk pada uraian pendapat yang dikemukakan oleh Kurniawan (2014:102) menjelaskan bahwa pengujian validitas ini dipergunakan untuk melaksanakan pengukuran pada instrument penelitian yang dipergunakan di dalam melaksanakan penelitian, apakah instrument yang dipergunakan tersebut sudah memiliki keabsahan atau belum. Kuisioner dinyatakan telah valid bilamana pertanyaan-pertanyaan yang termuat pada kuisioner tersebut memiliki kemampuan dalam memprediksi atau mempengaruhi objek yang sedang diteliti. Bilamana nilai dari $r_{h i t u n g}$ lebih tinggi dibanding pada $\mathbf{r}_{\text {tabel}}$, dengan demikian pertanyaan atau soal dari kuisioner tersebut sudah valid atau layak

\section{Uji reliabilitas}

Merujuk pada uraian pendapat yang dikemukakan oleh Kurniawan (2014: 102) menjelaskan bahwa pengujian reliabilitas ialah suatu pengujian yang dilaksanakan untuk tujuan mengukur atau menilai instrument penelitian yang dipergunakan tersebut sudah memiliki kehandalan dalam memprediksi atau mempengaruhi pada objek yang sedang diteliti. Bilamana jawaban yang dihasilkan oleh instrument tersebut stabil dan konsisten dari waktu ke waktu, maka kuisioner tersebut dinyatakan sudah handal atau reliabel atau bila nilai dari cronbach alpha lebih tinggi dibanding pada 0.6 .

\section{Uji asumsi klasik}

\section{Uji normalitas}

Merujuk pada uraian pendapat yang dikemukakan oleh Kurniawan (2014:156) menjelaskan bahwa tujuan dari pengujian normalitas ialah untuk melihat apakah di dalam permodelan regresi, variabel residual atau pengganggu tersebut mempunyai distribusi yang normal, sebagaimana dipahami bahwa pengujian $\mathrm{F}$ dan pengujian $\mathrm{t}$ memiliki asumsi bahwa nilai dari residual tersebut berdistribusi normal. Data dikatakan memiliki distribusi normal bilamana nilai signifikansi dari Kolmogorov-Smirnov lebih tinggi dibanding pada 0.05

\section{Uji multikolonieritas}

Merujuk pada uraian pendapat oleh Kurniawan (2014:157) mengungkapkan bahwa pengujian multikolonieritas dilaksanakan untuk melaksanakan pengujian akankah data yang dipergunakan terdapat hubungan korelasi diantara variabel bebas atau independen. Pada umumnya, nilai yang dipergunakan untuk memperlihatkan sifat multikolinearitas ialah nilai VIF lebih kecil dibanding 10 atau nilai tolerance besar dari 0.10 , jika nilai pengujian tersebut memenuhi asumsi yang dikemukakan di atas, dengan demikian bisa dihasilkan suatu simpulan bahwa data tersebut tidak terdapat sifat multikolinearitas yang ada di dalam antar variabel bebas atau independen.

\section{Uji heteroskedastisitas}

Merujuk pada uraian pendapat yang dikemukakan oleh Kurniawan (2014:156) menjelaskan bahwa tujuan dari pengujian heteroskedastisitas ialah melihat apakah di dalam permodelan regresi tersebut terdapat ketidaksamaan variance yang ada pada 
residual dari satu pengamatan tertentu pada pengamatan yang lainnya. Bilamana nilai dari variance yang ada pada residual dari suatu pengamatan pada pengamatan yang lainnya nilainya konstan, dengan demikian dinyatakan sebagai homokedastisitas, dan sedangkan dinyatakan sebagai heterokedastitas bilamana nilai dari variance pada satu pengamatan ke pengamatan yang lainnya tersebut tidak tetap.l

\section{Model analisis data penelitian}

\section{Koefisien determinasi $\left(\mathbf{R}^{2}\right)$}

Merujuk pada uraian pendapat yang dikemukakan oleh Ghozali (2018: 97) menyatakan bahwa koefisien determinasi pada dasarnya ialah untuk mengukur atau memprediksi kapasitas dari variabel bebas atau independen dalam mempengaruhi terhadap variabel terikat atau dependen. Nilai dari koefisien determinan ini ialah interval dari angka nol sampai satu. Nilai Adjusted $R^{2}$ bisa memiliki nilai yang negatif, meskipun yang diharapkan memiliki nilai yang positif.

\section{Pengujian hipotesis secara parsial (Uji t)}

Merujuk pada uraian pendapat yang dikemukakan oleh Ghozali (2016:97) menjelaskan bahwa pengujian statistif t intinya ialah untuk memperlihatkan seberapa besar pengaruh secara parsial dari variabel bebas atau independen dalam menerangkan atau memprediksi variasi dari variabel terikat atau dependen dengan hipotesis nol $\left(\mathrm{H}_{0}\right)$ yang akan dilaksanakan pengujian apakah nilai parameter $\left(\mathrm{b}_{\mathrm{i}}\right)$ nilainya ialah nol dan untuk mengetahui apakah hipotesis diajukan diterima atau ditolak dilaksanakanlah dengan melaksanakan komparasi antara nilai dari $\mathrm{F}$ hitung dengan $\mathrm{F}$ tabel dengan kriteria sebagaimana berikut ini:

\section{Kriteria pengujian}

$\mathrm{H}_{0}$ : ditolak bilamana nilai dari signifikansi dari $\mathrm{t}_{\text {hitung }}$ lebih kecil dibanding pada nilai dari alpha.

$\mathrm{H}_{0}$ : diterima bilamana nilai dari signifikansi dari $t_{\text {hitung }}$ lebih besar dibanding pada nilai dari alpha.

\section{Pengujian hipotesis secara simultan (Uji F)}

Merujuk pada uraian pendapat oleh Ghozali (2013:171) menjelaskan bahwa Pengujian hipotesis simultan (uji F) memiliki kegunaan untuk melihat apakah variabel bebas atau independen memberikan sumbangan pengaruh atau dapat memprediksi pada variabel dependen secara bersama-sama. Untuk mengetahui apakah hipotesis diajukan diterima atau ditolak dilaksanakanlah dengan melaksanakan komparasi antara nilai dari $\mathrm{F}$ hitung dengan $\mathrm{F}$ tabel dengan kriteria sebagaimana berikut ini:

\section{Kriteria pengujian}

$\mathrm{H}_{\mathrm{a}}$ diterima bilamana $\mathrm{F}_{\text {hitung }}$ lebih tinggi dibanding $\mathrm{F}_{\text {tabel }}$ dan sedangkan untuk nilai signifikansi lebih rendah dibanding pada $0,05, \mathrm{H}_{\mathrm{o}}$ ditolak bilamana $\mathrm{F}_{\text {hitung }}$ lebih rendah dibanding $\mathrm{F}_{\text {tabel }}$ dan sedangkan untuk untuk nilai signifikansi lebih tinggi dibanding pada 0,05 .

\section{HASIL DAN PEMBAHASAN}

\section{Hasil statistik deskriptif}

Di bawah ini ialah statistif deskriptif yang bisa berupa jawaban dari standar deviasi, rata-rata, maksimum dan minimum dari responden, hal ini bisa ditinjau berdasarkan pada Tabel 1 sebagaimana di bawah ini: 
Tabel 1. Uji deskriptif desriptif statistik

\begin{tabular}{lccccc} 
& N & Minimum Maximum & Mean & Std. Deviation \\
\hline Kualitas Pelayanan & 84 & 23 & 48 & 39,75 & 4,491 \\
Harga & 84 & 21 & 42 & 35,81 & 4,161 \\
Lokasi & 84 & 24 & 43 & 36,57 & 3,720 \\
Kepuasan Pelanggan & 84 & 24 & 47 & 40,18 & 4,212 \\
Valid N (listwise) & 84 & & & & \\
\hline
\end{tabular}

Sumber: Data diolah, 2020

Merujuk pada lampiran dari Tabel 1 yang dilampirkan tersebut di atas, dengan demikian bisa dilihat bahwa standar deviasi, nilai rata-rata (Mean), nilai maksimum, serta nilai minimum dari variabel bebas atau independen dari kualitas layanan $\left(\mathrm{X}_{1}\right)$, variabel bebas atau independen dari harga $\left(\mathrm{X}_{2}\right)$, variabel bebas atau independen dari lokasi $\left(\mathrm{X}_{3}\right)$ dan variabel terikat atau dependen dari kepuasan pelanggan (Y) ialah sebagaimana berikut ini: 1). Variabel bebas atau independen dari kualitas layanan $\left(\mathrm{X}_{1}\right)$ dengan sampel ialah sejumlah 84 memiliki nilai minimum 23 dan nilai maksimum ialah senilai 48, sementara itu untuk nilai rata-rata (Mean) 39.75 dan untuk standar deviasi ialah senilai 4.491. 2). Variabel bebas atau independen dari harga $\left(\mathrm{X}_{2}\right)$ dengan sampel ialah sejumlah 84 memiliki nilai minimum 21 dan nilai maksimum ialah senilai 42, sementara itu untuk nilai rata-rata (Mean) 35.81 dan untuk standar deviasi ialah senilai 4.161. 3).Variabel bebas atau independen dari lokasi $\left(\mathrm{X}_{3}\right)$ dengan sampel ialah sejumlah 84 memiliki nilai minimum 24 dan nilai maksimum ialah senilai 43, sementara itu untuk nilai rata-rata (Mean) 36.57 dan untuk standar deviasi ialah senilai 3.720. 4).Variabel terikat atau dependen dari kepuasan pelanggan (Y) dengan sampel ialah sejumlah 84 memiliki nilai minimum 23 dan nilai maksimum ialah senilai 48, sementara itu untuk nilai rata-rata (Mean) 39.75 dan untuk standar deviasi ialah senilai 4.491.

\section{Uji validitas dan reliabilitas}

\section{Uji validitas}

Pengujian validitas memiliki tujuan untuk melaksanakan pengukuran berkenaan dengan variabel yang dipergunakan tersebut memang memiliki kemampuan atau kapasitas dalam melaksanakan pengukuran terhadap objek yang sedang dilaksanakan pengukuran. Di dalam pelaksanaan penelitian ini, pengujian validitas yang dilaksanakan ialah dengan memperbandingkan nilai dari Correlated item-Total Correlation dengan mempergunakan $\mathrm{r}$ tabel, sedangkan untuk degree of freedom $(\mathrm{df})=\mathrm{n}-2, \mathrm{n}$ di dalam penelitian ini didefinisikan sebagai jumlah dari sampel penelitian, dan sedangkan untuk alpha ialah 0.05 . bilamana $\mathrm{r}$ hitung tersebut lebih tinggi dibanding pada $\mathrm{r}$ tabel, dan nilainya tersebut positif, dengan demikian butir dari indikator atau pertanyaan tersebut dinyatakan sebagai sudah valid. Dengan demikian $r$ tabel dari $n=(\mathrm{N}-2)=(30-2)$, yakni senilai 0.361 . 
Tabel 2. Uji validitas kualitas pelayanan (X1)

\begin{tabular}{|l|c|c|c|c|c|}
\hline $\begin{array}{c}\text { Item } \\
\text { Pernyataan }\end{array}$ & $\mathbf{r}_{\text {hitung }}$ & Signifikan & $\mathbf{r}_{\text {tabel }}$ & Signifikan & Keterangan \\
\hline $\mathrm{X}_{1.1}$ & 0,817 & 0,000 & 0,361 & 0,05 & Valid \\
\hline $\mathrm{X}_{1.2}$ & 0,769 & 0,000 & 0,361 & 0,05 & Valid \\
\hline $\mathrm{X}_{1.3}$ & 0,769 & 0,000 & 0,361 & 0,05 & Valid \\
\hline $\mathrm{X}_{1.4}$ & 0,721 & 0,000 & 0,361 & 0,05 & Valid \\
\hline $\mathrm{X}_{1.5}$ & 0,721 & 0,000 & 0,361 & 0,05 & Valid \\
\hline $\mathrm{X}_{1.6}$ & 0,772 & 0,000 & 0,361 & 0,05 & Valid \\
\hline $\mathrm{X}_{1.7}$ & 0,852 & 0,000 & 0,361 & 0,05 & Valid \\
\hline $\mathrm{X}_{1.8}$ & 0,826 & 0,000 & 0,361 & 0,05 & Valid \\
\hline $\mathrm{X}_{1.9}$ & 0,829 & 0,000 & 0,361 & 0,05 & Valid \\
\hline $\mathrm{X}_{1.10}$ & 0,690 & 0,000 & 0,361 & 0,05 & Valid \\
\hline
\end{tabular}

Sumber: Data diolah, 2020

Tabel 3. Uji validitas harga $(\mathrm{X} 2)$

\begin{tabular}{|l|c|c|c|c|c|}
\hline $\begin{array}{c}\text { Item } \\
\text { Pertanyaan }\end{array}$ & r hitung & Signifikan & $\mathbf{r}_{\text {tabel }}$ & Signifikan & Keterangan \\
\hline $\mathrm{X}_{2.1}$ & 0,809 & 0,000 & 0,361 & 0,05 & Valid \\
\hline $\mathrm{X}_{2.2}$ & 0,842 & 0,000 & 0,361 & 0,05 & Valid \\
\hline $\mathrm{X}_{2.3}$ & 0,900 & 0,000 & 0,361 & 0,05 & Valid \\
\hline $\mathrm{X}_{2.4}$ & 0,779 & 0,000 & 0,361 & 0,05 & Valid \\
\hline $\mathrm{X}_{2.5}$ & 0,684 & 0,000 & 0,361 & 0,05 & Valid \\
\hline $\mathrm{X}_{2.6}$ & 0,843 & 0,000 & 0,361 & 0,05 & Valid \\
\hline $\mathrm{X}_{2.7}$ & 0,844 & 0,000 & 0,361 & 0,05 & Valid \\
\hline $\mathrm{X}_{2.8}$ & 0,800 & 0,002 & 0,361 & 0,05 & Valid \\
\hline $\mathrm{X}_{2.9}$ & 0,539 & 0,000 & 0,361 & 0,05 & Valid \\
\hline
\end{tabular}

Sumber: Data diolah, 2020

Tabel 4. Uji validitas lokasi (X3)

\begin{tabular}{|l|c|c|c|c|c|}
\hline $\begin{array}{c}\text { Item } \\
\text { Pertanyaan }\end{array}$ & r hitung & Signifikan & $\mathbf{r}_{\text {tabel }}$ & Signifikan & Keterangan \\
\hline $\mathrm{X}_{3.1}$ & 0,866 & 0,000 & 0,361 & 0,05 & Valid \\
\hline $\mathrm{X}_{3.2}$ & 0,450 & 0,013 & 0,361 & 0,05 & Valid \\
\hline $\mathrm{X}_{3.3}$ & 0,482 & 0,007 & 0,361 & 0,05 & Valid \\
\hline $\mathrm{X}_{3.4}$ & 0,585 & 0,001 & 0,361 & 0,05 & Valid \\
\hline $\mathrm{X}_{3.5}$ & 0,765 & 0,000 & 0,361 & 0,05 & Valid \\
\hline $\mathrm{X}_{3.6}$ & 0,739 & 0,000 & 0,361 & 0,05 & Valid \\
\hline $\mathrm{X}_{3.7}$ & 0,643 & 0,000 & 0,361 & 0,05 & Valid \\
\hline $\mathrm{X}_{3.8}$ & 0,824 & 0,000 & 0,361 & 0,05 & Valid \\
\hline $\mathrm{X}_{3.9}$ & 0,737 & 0,000 & 0,361 & 0,05 & Valid \\
\hline
\end{tabular}

Sumber: Data diolah, 2020

Tabel 5. Uji validitas kepuasan pelanggan (Y)

\begin{tabular}{|l|c|c|c|c|c|}
\hline $\begin{array}{c}\text { Item } \\
\text { Pertanyaan }\end{array}$ & r hitung & Signifikan & $\mathbf{r}_{\text {tabel }}$ & Signifikan & Keterangan \\
\hline $\mathrm{Y}_{1.1}$ & 0,891 & 0,000 & 0,361 & 0,05 & Valid \\
\hline $\mathrm{Y}_{1.2}$ & 0,769 & 0,000 & 0,361 & 0,05 & Valid \\
\hline $\mathrm{Y}_{1.3}$ & 0,869 & 0,000 & 0,361 & 0,05 & Valid \\
\hline $\mathrm{Y}_{1.4}$ & 0,770 & 0,000 & 0,361 & 0,05 & Valid \\
\hline $\mathrm{Y}_{1.5}$ & 0,776 & 0,000 & 0,361 & 0,05 & Valid \\
\hline $\mathrm{Y}_{1.6}$ & 0,863 & 0,000 & 0,361 & 0,05 & Valid \\
\hline $\mathrm{Y}_{1.7}$ & 0,694 & 0,000 & 0,361 & 0,05 & Valid \\
\hline $\mathrm{Y}_{1.8}$ & 0,404 & 0,027 & 0,361 & 0,05 & Valid \\
\hline $\mathrm{Y}_{1.9}$ & 0,507 & 0,004 & 0,361 & 0,05 & Valid \\
\hline $\mathrm{Y}_{1.10}$ & 0,863 & 0,000 & 0,361 & 0,05 & Valid \\
\hline
\end{tabular}

Sumber: Data diolah, 2020 
Merujuk pada Tabel 2 sampai dengan Tabel 5 yang disajikan tersebut di atas memerlihatkan bahwa nilai dari $r_{\text {hitung }}$ lebih tinggi dibanding pada $r_{\text {tabel }}$, sehingga dapat disimpulkan bahwa pernyataan di atas memenuhi kriteria uji validitas.

\section{Uji reliabilitas}

Pengujian reliabilitas yang dipergunakan dalam melaksanakan pengukuran bahwa variabel yang dipergunakan tersebut terbebas dari kesalahan atau kegagalan, dengan demikian mendapatkan hasil yang stabil arau konsisten walaupun dilaksanakan pengujian berulang kali. Sebuah instumen atau alat penelitian bisa dinyatakan sebagai memiliki keandalan atau reliabel bilamana nilai dari Cronbach Alpha lebih tinggi dibanding pada 0.7. Merujuk pada hasil penganalisisan dengan berbantuan SPSS dihasilkan pengujian reliabilitas sebagaimana berikut:

Tabel 6. Hasil uji reliabilitas

\begin{tabular}{|c|l|c|c|c|}
\hline No & \multicolumn{1}{|c|}{ Variabel } & $\begin{array}{c}\text { Nilai Cronbach' } \\
\text { Alpha }\end{array}$ & Kriteria & Kesimpulan \\
\hline 1 & Kualitas Pelayanan & 0,835 & 0,60 & Reliabel \\
\hline 2 & Harga & 0,871 & 0,60 & Reliabel \\
\hline 3 & Lokasi & 0,862 & 0,60 & Reliabel \\
\hline 4 & Kepuasan Pelanggan & 0,862 & 0,60 & Reliabel \\
\hline
\end{tabular}

Sumber: Data diolah, 2020

Merujuk pada hasil dari pengujian reliabel dalam Tabel 6 tersebut di atas memperlihatkan bahwa keseluruhan variabel bebas atau independen memiliki nilai koefisien alpha yang lebih tinggi dibanding pada 0.6, dengan demikian hasil dari pengujian reliabel terhadap keseluruhan variabel ialah handal atau reliabel. Item tersebut untuk tiap variabel dinyatakan sebagai layak untuk dipergunakan menjadi instrument pengukur di dalam uji statistic.

\section{Uji asumsi klasik}

\section{Uji normalitas}

Pengujian normalitas ialah untuk melihat apakah di dalam permodelan regresi, variabel residual atau pengganggu tersebut mempunyai distribusi yang normal, sebagaimana dipahami bahwa pengujian $\mathrm{F}$ dan pengujian $\mathrm{t}$ memiliki asumsi bahwa nilai dari residualtersebut berdistribusi normal. Merujuk pada hasil pengujian dengan berbantuan SPSS mengenai pengujian normalitas yang mempergunakan grafik histogram one sample kolmogorov-smirnov test dan probability plot, dengan demikian hasil yang didapatkan ialah sebagaimana di bawah ini:

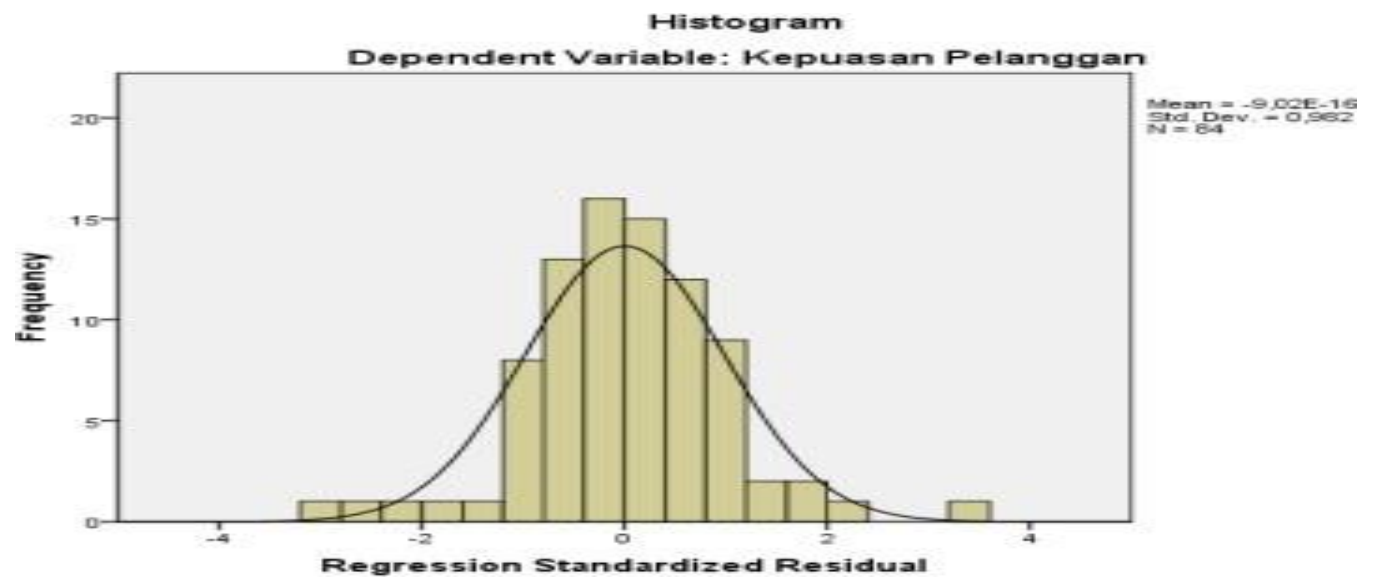

Gambar 1. Pengujian normalitas grafik histogram 
Berdasarkan Gambar 1, terlihat bahwa gambar garis berbentuk lonceng, tidak melonceng kekiri ataupun kekanan. Hal semacam ini menunjukan bahwa data tersebut memiliki distribusi normal dan sesuai dengan asumsi normalitas.

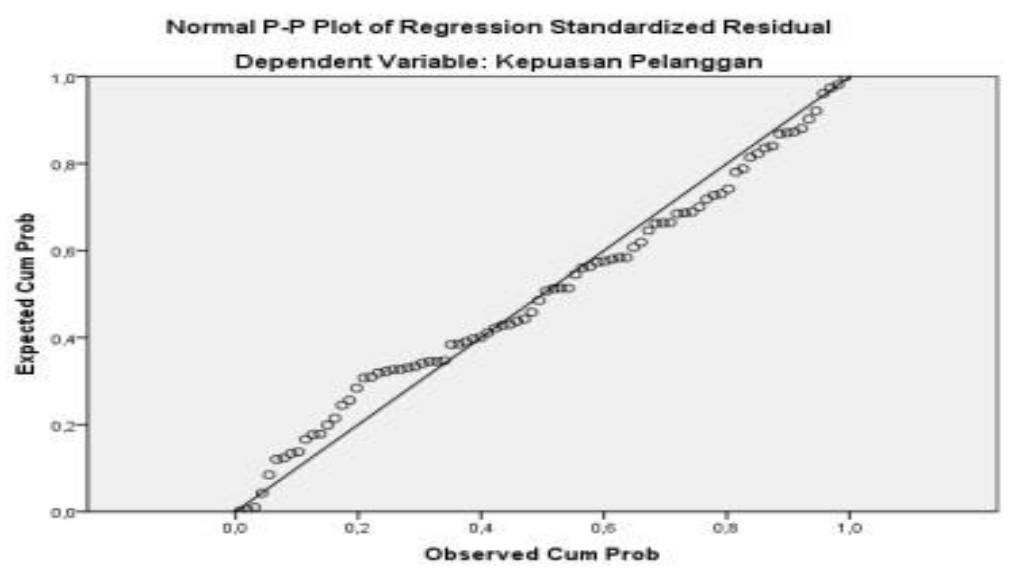

Gambar 2. Pengujian normalitas grafik normal p-plot Sumber: Data diolah, 2020

Berdasarkan pada Gambar 2, Normal P.P Plot of Regression Standardized Residual yang disajikan tersebut di atas memperlihatkan titik menyebar di sekitar diagonal dan penyebaran dari titik-titik tersebut mengikuti pada arah dari garis diagonal dengan demikian bisa dihasilkan suatu simpulan bahwa data model dari regresi tersebut memiliki distribusi yang normal

Tabel 7. Pengujian one sample Kolgoromov

\section{One-Sămple Kolmogorov-Smirnov Test}

\begin{tabular}{|ll|r|}
\hline & & Unstandardized Residual \\
\hline N & & 84 \\
Normal Parameters & Mean &, 0000000 \\
& Std. Deviation & 2,03421528 \\
Most Extreme Differences & Absolute & 102 \\
& Positive &, 064 \\
& Negative & -102 \\
Kolmogorov-Smimov Z & &, 934 \\
Asymp. Sig. (2-tailed) &, 348 \\
\hline a. Test distributionis Normal. & \\
b. Calculated from data. & \\
Sumber: Data diolah, & 2020 \\
\end{tabular}

Sumber: Data diolah, 2020

Merujuk pada Tabel 7 yang disajikan tersebut di atas, hasil dari pengujian normalitas dengan mempergunakan nilai Asymp. Sig. (2-tailed) memperlihatkan bahwa nilai dari signifikannya ialah senilai 0,348>0,05, dengan demikian hasil dari nilai Asymp. Sig. (2-tailed) memperlihatkan bahwa data tersebut memiliki distribusi yang normal.

\section{Uji multikolonieritas}

Pengujian multikolonieritas dilaksanakan untuk melaksanakan pengujian akankah data yang dipergunakan tersebut terdapat hubungan korelasi diantara variabel bebas atau independen. Berikut ini ialah hasil dari pengujian multikolinearitas, yakni sebagaimana pada Tabel 8.

Merujuk pada Tabel 8 yang disajikan tersebut di atas, dengan demikian memperlihatkan bahwa hasil dari nilai VIF variabel kualitas pelayanan yaitu 5,225, harga 6,635, dan lokasi 3,366 lebih rendah dibanding pada 10 dan sedangkan untuk nilai dari 
Tolerance untuk variabel kualtias pelayanan 0,191, harga 0,151, dan lokasi 0,297 lebih tinggi dibanding pada 0,10 . Hal semacam ini menunjukan tidak berlangsung atau ada multikolinearitas.

Tabel 8. Hasil uji multikolonieritas

\begin{tabular}{llcc}
\hline \multirow{2}{*}{ Model } & \multicolumn{2}{c}{ Colinearity Statistics } \\
\cline { 3 - 4 } & (Constant) &, 191 & VIF \\
\hline Kualitas pelayanan &, 151 & 5,225 \\
Harga &, 297 & 6,635 \\
Lokasi & & 3,366 \\
\hline
\end{tabular}

Sumber: Data diolah, 2020

\section{Uji heteroskedastisitas}

Tujuan dari pengujian heteroskedastisitas ialah melihat apakah di dalam permodelan regresi tersebut terdapat ketidaksamaan variance yang ada pada residual dari satu pengamatan tertentu pada pengamatan yang lainnya. Pengujian heterokedastisitas yang dipergunakan di dalam pelaksanaan ini ialah dengan mempergunakan pengujian Glejser dan juga metode grafik scatterplot, yakni dengan cara mengkomparasikan nilai dari probabilitas dengan nilai dari alpha, yakni 0.05. Jika nilai probabilitas lebih tinggi dibanding pada 0,05, maka tidak terjadi Heteroskedastisitas. Hasil dari pengujian heterokedastisitas bisa ditinjau sebagaimana berikut ini:

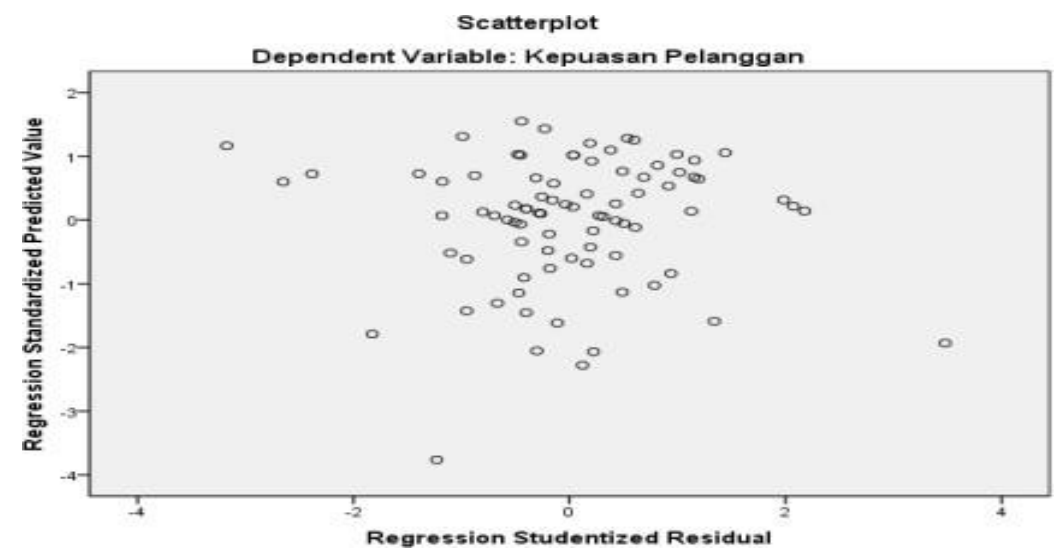

Gambar 3. Pengujian heteroskedastisitas

Berdasarkan pada Gambar 3. yang disajikan tersebut di atas bisa ditinjau bahwa data tersebut sifatnya menyebar dengan tidak beraturan, sehingga tidak menghasilkan sebuah pola serta menjauhi titik 0 , maka data tersebut dinyatakan terbebas dari heteroskedastisitas.

Tabel 9. Uji heteroskedastisitas pengujian glejser

\begin{tabular}{lrrrrrr}
\hline Model & \multicolumn{9}{c}{ Coefficients $^{\mathbf{a}}$} \\
& \multicolumn{2}{c}{$\begin{array}{c}\text { Unstandardized } \\
\text { Coefficients }\end{array}$} & $\begin{array}{c}\text { Standardized } \\
\text { Coefficients }\end{array}$ & \multirow{2}{*}{ t } & \multirow{2}{*}{ Sig. } \\
\cline { 2 - 5 } & \multicolumn{1}{c}{ B } & Std Error & Beta & & \\
\hline 1 & 1,965 & 1,555 & & 1,264 &, 210 \\
Kualitas Pelayanan &,- 005 &, 078 &,- 018 &,- 070 &, 944 \\
Harga &, 066 &, 095 &, 198 &, 691 &, 491 \\
Lokasi &,- 072 &, 076 &,- 193 &,- 946 &, 347 \\
\hline
\end{tabular}

a. Dependent Variable: RES2

Sumber: Data diolah, 2020 
Merujuk pada Tabel 9 memperlihatkan bahwa hasil dari pengujian glejser kualitas pelayanan memiliki nilai signifikan 0,944, harga memiliki nilai signifikan 0,491, lokasi memiliki nilai signifikan 0,347. Dengan demikian bisa dihasilkan suatu simpulan bahwa data tersebut di atas terbebas dari sifat heteroskedastisitas.

\section{Hasil analisis}

Model analisis penelitian ini adalah analisis regresi linear berganda. Fungsi dari metode analisis regresi linear ini ialah untuk memahami pengaruh keterkaitan hubungan atau untuk memprediksi besaran pengaruh yang ditimbulkan oleh variabel bebas atau independen terhadap variabel terikat atau dependen. Rumus perhitungan persamaan regresi berganda adalah sebagaimana di bawah ini:

Tabel 10. Hasil analisis regresi linear berganda

\begin{tabular}{|c|c|c|c|c|c|c|}
\hline \multicolumn{7}{|c|}{ Coefficients ${ }^{a}$} \\
\hline \multirow{2}{*}{\multicolumn{2}{|c|}{ Model }} & \multicolumn{2}{|c|}{ Unstandardized Coefficients } & $\begin{array}{c}\text { Standardized } \\
\text { Coefficients }\end{array}$ & \multirow[b]{2}{*}{$\mathrm{t}$} & \multirow[b]{2}{*}{ Sig. } \\
\hline & & $B$ & Std. Error & Beta & & \\
\hline \multirow[t]{4}{*}{1} & (Constant) & 5,297 & 2,294 & & 2,309 &, 024 \\
\hline & Kualitas Pelayanan & 294 & ,116 & ,314 & 2,542 & ,013 \\
\hline & Harga &, 392 &, 141 &, 387 & 2,786 &, 007 \\
\hline & Lokasi & 250 &, 112 & 221 & 2,228 &, 029 \\
\hline
\end{tabular}

Sumber: Data diolah, 2020

Model Regresi yang dipergunakan di dalam penelitian ini ialah sebagaimana berikut:

$$
\mathrm{Y}=5,297+0,294 \mathrm{X}_{1}+0,392 \mathrm{X}_{2}+0,250 \mathrm{X}_{3}+\mathrm{e}
$$

\section{Konstanta $(\mathbf{a})=\mathbf{5 , 2 9 7}$}

Konstanta mempunyai nilai sebanyak 5,297, hal semacam ini memperlihatkan bahwa bilamana variabel bebas atau independen dari kualitas pelayanan $\left(\mathrm{X}_{1}\right)$, variabel bebas atau independen harga $\left(\mathrm{X}_{2}\right)$ dan variabel bebas atau independen $\left(\mathrm{X}_{3}\right)$ tersebut adalah 0 (nol), dengan demikian variabel terikat atau independen dari Kepuasan pelanggan (Y) nilainya ialah 5,297.

\section{Variabel produk $\left(X_{1}\right)=0,294$}

Variabel $X_{1}$ memiliki nilai koefisien regresi ialah senilai 0,294 , bilamana terjadi atau terdapat perubahan dari variabel bebas atau independen kualitas pelayanan tersebut senilai 1 poin atau 1\%, dengan demikian dapat meningkatkan nilai yang ada pada variabel terikat atau dependen dari kepuasan pelanggan senilai 0,294.

\section{Variabel promosi $\left(\mathbf{X}_{2}\right)=0,392$}

Variabel $X_{2}$ memiliki nilai koefisien regresi ialah senilai 0,392 , bilamana terjadi atau terdapat perubahan dari variabel bebas atau independen harga tersebut senilai 1 poin atau $1 \%$, dengan demikian dapat meningkatkan nilai yang ada pada variabel terikat atau dependen dari kepuasan pelanggan senilai 0,392.

\section{Variabel saluran distribusi $\left(X_{3}\right)=0,250$}

Variabel $\mathrm{X}_{3}$ memiliki nilai koefisien regresi ialah senilai 0,250 , bilamana terjadi 
atau terdapat perubahan dari variabel bebas atau independen lokasi tersebut senilai 1 poin atau $1 \%$, dengan demikian dapat meningkatkan nilai yang ada pada variabel terikat atau dependen dari kepuasan pelanggan senilai 0.250 .

\section{Koefisien determinasi}

Di dalam pelaksanaan penelitian ini, model analisis yang dipergunakan ialah analisis regresi linear berganda (multiple regression). Tujuan dari pelaksanaan penganalisisan ini ialah agar mengetahui atau menunjukkan besaran pengaruh yang dihasilkan atau diprediksikan dari variabel bebas atau independen dari kualitas pelayanan, variabel bebas atau independen harga, dan variabel bebas atau independen lokasi pada varibael terikat atau dependen dari kepuasan pelanggan yang ada di dalam PT. Dwi karya sartika dengan berbantuan SPSS. Formulasi dari regresi berganda tersebut ialah sebagaimana di bawah ini:

Tabel 11. Koefisien determinasi

\begin{tabular}{|l|c|r|r|r|}
\multicolumn{7}{|c|}{ Model Summary $^{\circ}$} \\
\hline Model & R & R Square & $\begin{array}{c}\text { Adjusted R } \\
\text { Square }\end{array}$ & $\begin{array}{c}\text { Std. Error of the } \\
\text { Estimate }\end{array}$ \\
\hline 1 &, $876^{\circ}$ &, 767 &, 758 & 2,072 \\
\hline
\end{tabular}

a. Predictors: (Constant), Lokasi, Kualitas Pelayanan, Harga

b. Dependent Variable: Kepuasan Pelanggan

Sumber: Data diolah, 2020

Merujuk pada Tabel 11 yang disajikan tersebut di atas memperlihatkan bahwa nilai dari Adjusted $R$ Square ialah senilai 0,758, dengan demikian memperlihatkan bahwa kemampuan atau kapasitas yang ada pada variabel bebas atau indpenden dari Kualitas pelayanan $\left(\mathrm{X}_{1}\right)$, variabel bebas atau indpenden dari Harga $\left(\mathrm{X}_{2}\right)$, dan variabel bebas atau indpenden dari Lokasi $\left(\mathrm{X}_{3}\right)$ dalam mempengaruhi atau memprediksikan variabel terikat atau dependen dari Kepuasan pelanggan (Y) ialah senilai 75,8\% dan sedangkan untuk sisa yang senilai $24,2 \%$ dipengaruhi atau diprediksikan variabelvariabel independen yang tidak diteliti.

\section{Hasil uji simultan (Uji F)}

Pengujian F ini memiliki tujuan agar memperlihatkan apakah keseluruhan dari variabel bebas atau independen yang dilibatkan di dalam permodelan memiliki sumbangan pengaruh pada variabel terikat atau dependen secara simultan atau bersamasama antara variabel bebas atau independen dari kualitas pelayanan, lokasi dan harga dalam memprediksikan atau mempengaruhi variabel terikat atau dependen dari kepuasan pelanggan.

$\mathrm{H}_{\mathrm{a}}$ diterima bilamana $\mathrm{F}_{\text {hitung }}$ lebih tinggi dibanding $\mathrm{F}_{\text {tabel }}$ dan sedangkan untuk nilai signifikansi lebih rendah dibanding pada 0,05, dengan demikian variabel bebas atau independen memberikan sumbangan pengaruh pada variabel terikat atau dependen secara simultan atau bersama-sama.

$\mathrm{H}_{\mathrm{o}}$ ditolak bilamana $\mathrm{F}_{\text {hitung }}$ lebih rendah dibanding $\mathrm{F}_{\text {tabel }}$ dan sedangkan untuk untuk nilai signifikansi lebih tinggi dibanding pada 0,05 , dengan demikian variabel bebas atau independen tidak memberikan sumbangan pengaruh pada variabel terikat atau dependen secara simultan atau bersama-sama. 
Tabel 12. Hasil uji simultan

\begin{tabular}{|c|c|c|c|c|c|c|}
\hline \multicolumn{7}{|c|}{ ANOVA $^{\circ}$} \\
\hline & & Sum of Squares & $\mathrm{df}$ & Mean Square & $\bar{F}$ & Sig. \\
\hline \multirow[t]{3}{*}{1} & Regression & 1128,865 & 3 & 376,288 & 87,647 &, $000^{2}$ \\
\hline & Residual & 343,457 & 80 & 4,293 & & \\
\hline & Total & 1472,321 & 83 & & & \\
\hline
\end{tabular}

Sumber: Data diolah, 2020

Nilai dari $\mathrm{F}_{\text {tabel }}$ yang ditinjau berdasarkan pada nilai dari $\mathrm{df}_{1}$ dan juga $\mathrm{df}_{2}$. Nilai dari $\mathrm{df}_{1}=\mathrm{k}-1$ dan sedangkan untuk nilai dari $\mathrm{df}_{2}=\mathrm{n}-\mathrm{k}$. Jumlah dari sampel penelitian $(\mathrm{n})=$ 84 , jumlah variabel bebas dan terikat $(\mathrm{k})=4$. Dengan demikian dihasilkanlah nilai dari $\mathrm{df}_{1}=4-1=3$ dan sedangkan untuk nilai dari $\mathrm{df}_{2}=84-4=80$. Merujuk pada tabel $\mathrm{F}$ tersebut di atas didapatkanlah nilai dari $\mathrm{df}_{1}=3$ dan sedangkan untuk nilai dari $\mathrm{df}_{2}=80$, nilai dari $F_{\text {tabel }}$ ialah senilai 2,72.

Untuk hasil dari pengujian $F$ didapatkanlah nilai dari $F_{\text {hitung }}$ ialah senilai 87,647 dengan tingkatan signifikansinya ialah 0.000 . sebab di dalam pelaksanaan penelitian ini, nilai signifikansinya ialah 0.00 yang lebih tinggi dibanding pada 0.05 , dan sedangkan untuk nilai dari $F_{\text {hitung }}$ ialah senilai 49,191 yang lebih tinggi dibanding pada nilai dari $F_{\text {tabel }}$ yang senilai 2.72, dengan demikian memperlihatkan bahwa variabel bebas atau independen dari kualitas pelayanan, variabel bebas atau independen dari harga dan variabel bebas atau independen dari lokasi memberikan sumbangan pengaruh signifikan dan positif pada variabel terikat atau independen dari kepuasan pelanggan pada PT. Dwi Karya Sartika.

\section{Uji parsial (Uji t)}

pengujian statistif parsial ialah untuk memperlihatkan seberapa besar pengaruh secara parsial dari variabel bebas atau independen dari pelayanan kualitas, variabel bebas atau independen lokasi dan variabel bebas atau independen harga dalam menerangkan atau memprediksi variasi dari variabel terikat atau dependen dari kepuasan pelanggan:

Tabel 13. Uji parsial (Uji t)

\begin{tabular}{|c|c|c|c|c|c|c|}
\hline & & $\mathrm{Cot}$ & cients $^{\mathrm{a}}$ & & & \\
\hline & Model & $\begin{array}{r}\text { Unst } \\
\text { co }\end{array}$ & $\begin{array}{l}\text { dardized } \\
\text { ficients }\end{array}$ & $\begin{array}{c}\text { Standardized } \\
\text { coefficients }\end{array}$ & $\mathbf{t}$ & Sig. \\
\hline & & B & Std. error & Beta & & \\
\hline & (Constant) & 5,297 & 2,294 & & 2,309 & ,024 \\
\hline 1 & $\begin{array}{l}\text { Kualitas } \\
\text { pelayanan }\end{array}$ & ,294 & ,116 & ,314 & 2,542 & ,013 \\
\hline & Harga & ,392 & , 141 & ,387 & 2,786 & ,007 \\
\hline & Lokasi &, 250 &, 112 & ,221 & 2,228 &, 029 \\
\hline
\end{tabular}

a. Dependent Variable: Kepuasan Pelanggan

Sumber: Data diolah, 2020

Nilai dari t-tabel yang ditinjau berdasarkan pada nilai dari $\mathrm{df}=\mathrm{n}-\mathrm{k}-1$ dengan tingkatan kesalahan 5\% (0.05). Jumlah dari sampel penelitian $(n)=84$, jumlah dari variabel independen dan juga variabel dependen $(\mathrm{k})=4$ dan sedangkan untuk alpha ialah senilai $0.05(5 \%)$. Dengan demikian dihasilkanlah nilai dari $\mathrm{t}_{\text {tabel }}$ dengan $\mathrm{df}=84-4-1=79$ dengan $\alpha=0.05$ ialah senilai 1,990 . 
Merujuk pada hasil dari pengujian t yang disajikan dalam tabel tersebut di atas memperlihatkan bahwa pengaruh dari variabel independen pada variabel dependen ialah sebagaimana berikut ini: 1). Kualitas pelayanan memiliki $t_{\text {hitung }} 2,542>t_{\text {tabel }} 1,990$ dan nilai signifikan sebesar $0.013<0.05$. dengan demikian bisa dihasilkan suatu simpulan bahwa variabel bebas atau independen dari kualitas pelayanan memberikan sumbangan pengaruh signifikan dan positif pada variabel terikat atau indpenden dari Kepuasan Pelanggan PT.Dwi Karya Sartika. 2).Harga memiliki nilai $t_{\text {hitung }} 2,786>t_{\text {tabel }} 1,990$ dan nilai signifikan sebesar $0.007<0.05$. dengan demikian bisa dihasilkan suatu simpulan bahwa variabel bebas atau independen dari lokasi memberikan sumbangan pengaruh signifikan dan positif pada variabel terikat atau indpenden dari Kepuasan Pelanggan PT.Dwi Karya Sartika. 3).Lokasi memiliki nilai thitung 2,228 $>t_{\text {tabel }}$ 1,990 dan signifikan sebesar $0.000<0.05$ dan nilai signifikan sebesar $0.000<0.05$ dan. dengan demikian bisa dihasilkan suatu simpulan bahwa variabel bebas atau independen dari lokasi memberikan sumbangan pengaruh signifikan dan positif pada variabel terikat atau indpenden dari Kepuasan Pelanggan PT.Dwi Karya Sartika.

\section{KESIMPULAN DAN SARAN}

\section{Kesimpulan}

Berdasarkan hasil penilitian dan pembahasan yang telah di uraikan pada bab sebelumnya, maka dapat ditarik kesimpulan yang terdiri dari: 1).Kualitas Pelayanan berpengaruh positif dan signifikanterhadap Kepuasan Pelanggan PT.Dwi Karya Sartika. 2).Harga berpengaruh positif dan signifikanterhadap Kepuasan Pelanggan PT.Dwi Karya Sartika. 3).Lokasi berpengaruh positif dan signifikanterhadap Kepuasan Pelanggan PT.Dwi Karya Sartika. 4).Kualitas Pelayanan, Harga dan Lokasi berpengaruh positif dan signifikanterhadap Kepuasan Pelanggan PT.Dwi Karya Sartika.

\section{Saran}

Para karyawan PT.Dwi Karya Sartika, diharapakn menambahmeningkatkan lagi kualitas pelayanan mereka agar dapat melayani dengan ramah sesuai denganyang diinginkanpelanggan

Harga yang ditetapkan PT.Dwi Karya Sartikasudah terjangkau, namun sebaiknya disesuaikan lagi dengan kualitas yang diterima pelanggan seperti diberikan minuman atau snack, sambil pelanggan menunggu perbaikan sepeda motornya agar pelanggan dapat merasa bahwa harga yang pelanggan keluarkan sudah sesuai dengan hasil yang diterima pelanggan.

Untuk lokasi sebaiknya dilakukan perluasan atau mencari tempat yang lebih luas dan menambah karyawan agar pelanggan merasa nyaman saat menunggu antrian dan pekerjaan karyawan juga bisa lebih cepat.

Bagi penelitian selanjutnya diharapkan dapat lebih mengembangkan teori-teori menyangkut variabel yang berhubungan dengan kepuasan pelanggan seperti citra merek, word of mouth dan produk.

\section{DAFTAR PUSTAKA}

Efnita, T. (2017). Pengaruh variasi produk, kualitas pelayanan, harga dan lokasi terhadap kepuasan konsumen pada wedding organizer. Jurnal Adibispreneur, 2(2), 107115.

Firdiyansyah, I. (2017). Pengaruh kualitas pelayanan, harga, dan lokasi terhadap kepuasan pelanggan pada warung gubrak KEPRI mall Kota Batam. Jurnal Riset 
Ekonomi Bidang Manajemen dan Akuntansi, 1(1), 1-9.

Ghozali, I. (2018). Aplikasi analisis multivariate dengan program IBM SPSS 25. Universitas Diponegoro: Semarang

Herlambang, S. (2014). Basic marketing (Dasar-dasar pemasaran) cara memahami ilmu pemasaran). Goyshen Publishing: Yogyakarta

Herlambang, Susatyo. (2014). Basic marketing (dasar-dasar pemasaran) cara mudah memahami ilmu pemasaran. Goyshen Publishing: Yogyakarta.

Kristianto, P. L. (2011). Psikologi pemasaran. CAPS: Yogyakarta:

Kurniawan, A. (2014). Metode Riset untuk ekonomi dan bisnis. Alfabeta: Bandung

Lupiyoadi, R. (2013). Manajemen pemasaran jasa. Salemba Empat: Jakarta

Paul, J. C. O., \& J., P. (2014). Perilaku konsumen dan strategi pemasaran (Edisi Kese). Salemba Empat: Jakarta

Philip, K., \& Amstrong, G. (2012). Prinsip-prinsip pemasaran (Edisi12 ed.). Erlangga: Jakarta

Sakdiyah, H., \& Budiyanto. (2016). Pengaruh kualitas pelayanan, harga dan lokasi terhadap kepuasan pelanggan Labatu SPA Batam. Jurnal Ilmu dan Riset Manajemen, 5(3).1-15

Sangadji, E. M., \& Sopiah. (2013). Perilaku konsumen. Andi Offset: Yogyakarta

Sangadji, S. dan E. M. (2019). Perilaku konsumen. Andi Offset: Yogyakarta

Sugiyono. (2016). Metode penelitian. Alfabeta: Bandung

Sunyoto, D. (2012). Dasar-dasar manajemen pemasaran. CAPS: Yogyakarta:

Tjiptono, F. (2014). Pemasaran jasa-prinsip, penerapan dan penelitian. Andi Offset: Yogyakarta

Tjiptono, F. (2018). Pemasaran jasa. Andi Offset: Yogyakarta 